\title{
Managed groundwater development for water-supply security in Sub-Saharan Africa: Investment priorities
}

\author{
Stephen Foster ${ }^{1,2 *}$, Albert Tuinhof ${ }^{3}$ and Frank van Steenbergen ${ }^{4}$ \\ ${ }^{1}$ Global Water Partnership, c/o Drottninggatan 33, SE-111-51 Stockholm, Sweden \\ ${ }^{2}$ International Association of Hydrogeologists, c/o PO Box 4130, Goring, Reading RG8-6BJ, UK \\ ${ }^{3}$ Acacia Water, 2805-RN Gouda, The Netherlands > \\ ${ }^{4}$ Meta-Meta Research, AJ-5223 Hertogenbosch, The Netherlands
}

\begin{abstract}
In numerous countries of Sub-Saharan Africa the strategic agenda of the water-sector is undergoing substantial change because of demographic pressure, climate change and economic transformation. Two new policy questions are arising from the need to make better use of available groundwater storage to improve water-supply security:

- What is the scope for promoting much increased groundwater use for irrigated agriculture, and how might the investment risks be reduced and sustainable outcomes ensured?

- How can the demand to expand urban groundwater use, for both further supplementing municipal water-supply systems and for direct in situ water supply, be best channelled to maximise the benefits whilst minimising the risks?

This 'new agenda' poses very different challenges from the long-standing requirement to provide rural water supplies of adequate coverage, reliability and quality (which, while still not yet fully addressed, is outside the scope of this paper). Balanced answers to these new questions are needed to provide a sound basis for appropriate investment policies on managed groundwater development and adequate institutional provisions for their implementation. They are discussed here from the standpoint of the GW-MATE experience in some World Bank-supported projects in eastern Africa during 20012010, together with a review of some developments in western Africa and insights from parts of Asia and Latin America.
\end{abstract}

Keywords: Sub-Saharan Africa, groundwater development, groundwater management, groundwater governance

\section{Groundwater development - the context}

\section{Vital for life and livelihoods}

Groundwater is the critical underlying resource for human survival and economic development in extensive droughtprone areas across Sub-Saharan Africa (Fig. 1). The accessibility of groundwater in traditional shallow hand-dug wells, springheads and seepage areas has always controlled the extent of human settlement beyond the major riparian tracts - and the widespread introduction of drilling rigs and water-well pumps from the 1970s enabled further extension of human activity (Foster, 1984). Today the dependence of rural water-supply on groundwater is undisputable, with the presence of successful water wells allowing the functioning of villages, clinics, schools, markets and livestock posts over very large land areas (note that in this paper the term 'water well' is used for all boreholes, and in smaller number deep hand-dug wells, equipped with pumps).

In recent years important new pressures for groundwater development have been observed, including:

- Rapidly increasing demand for urban water-supply provision at a range of scales - from improving water services in innumerable small (but rapidly expanding) towns to supplementary public and private water-supply sources in large conurbations

This paper was originally presented at the International Conference on Groundwater: Our Source of Security in an Uncertain Future, Pretoria, 19-21 September 2011.

* To whom all correspondence should be addressed.

용 +44 7854-890496; e-mail: IAHfoster@aol.com
- Growing interest in the prospect of accelerating groundwater use for agricultural irrigation - both for high-value crop production at the commercial scale, and for subsistence horticulture and drought-proofing some staple-crop cultivation.

In parallel with these trends, awareness of the need to conserve groundwater-dependent streamflows and aquatic ecosystems is also increasing.

Many parts of Sub-Saharan Africa are prone to severe drought, and at tropical latitudes there is increasing evidence of a direct correlation between drought propensity and persistent poverty. Thus there is a pressing need for investment in drought preparedness at a variety of scales, including the enhanced management of groundwater storage to 'buffer' drought impacts (Tuinhof et al., 2011). Groundwater resources generally offer notable drought resilience, which varies with the drainable volume of storage accessible in the aquifer concerned (determining the period during which 'current use' could be sustained from storage alone).

\section{Resource constraints}

Although the distribution of aquifers is now reasonably mapped, and has been well integrated by the BGR/IAH/ UNESCO Africa Groundwater Resources Map (WHYMAP, 2008), information on aquifer characteristics, groundwater recharge rates, flow regimes, quality controls and use remains rather patchy. This has tended to mean that in developmental circles groundwater is sometimes either the subject of 'unreasonable expectation' or not taken into 'serious consideration'. With this in mind, and in order to provide a general indication of the prospects for sustainable groundwater resource use, as a 


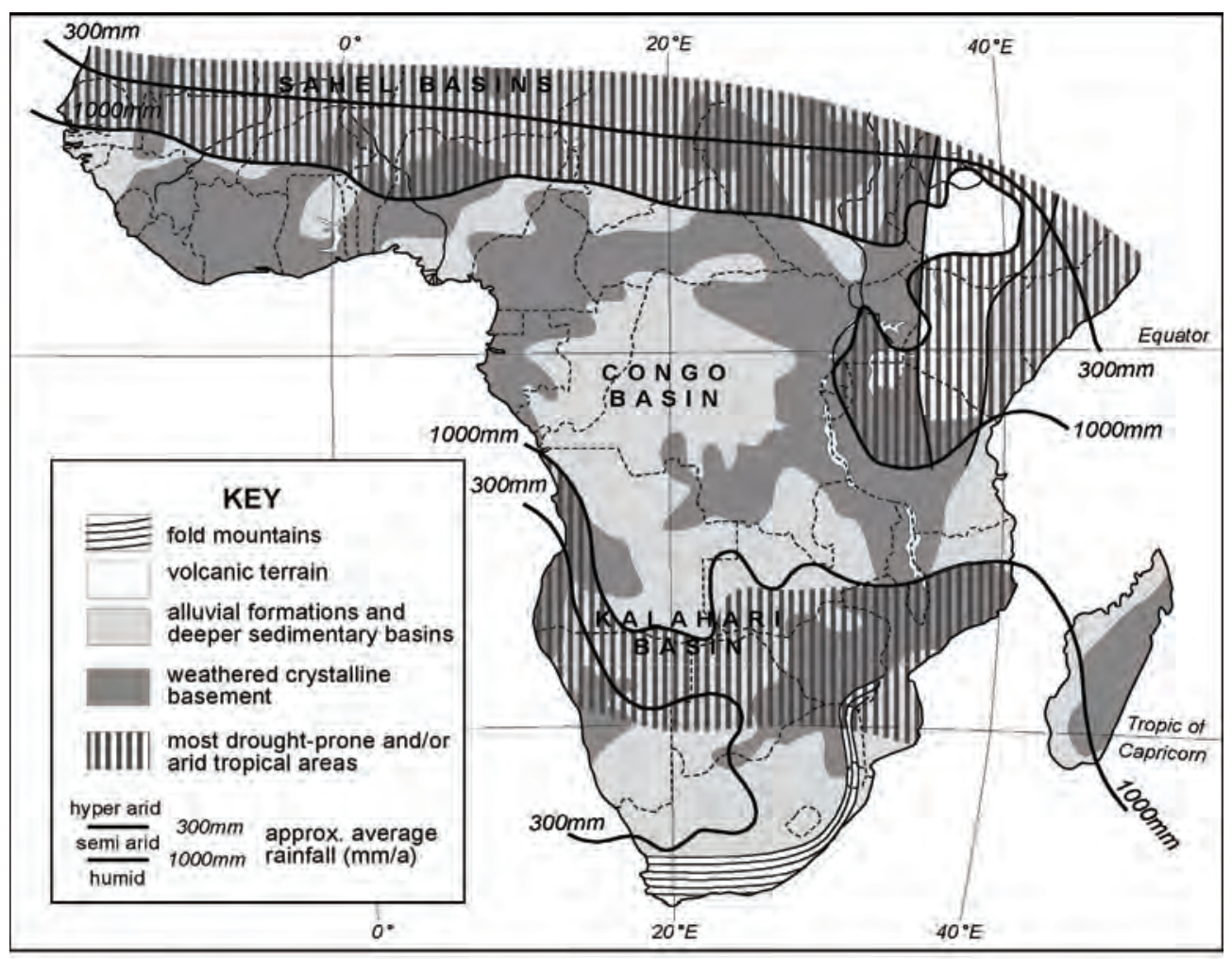

\begin{tabular}{|c|c|c|c|c|}
\hline AQUIFER CATEGORIES & $\begin{array}{c}\text { Thin Alluvial/ } \\
\text { Colluvial } \\
\text { Formations }\end{array}$ & $\begin{array}{l}\text { River \& Coastal } \\
\text { Alluvium }\end{array}$ & $\begin{array}{l}\text { Weathered } \\
\text { Crystalline } \\
\text { Basement }\end{array}$ & $\begin{array}{c}\text { Consolidated } \\
\text { Sandstones \& } \\
\text { Limestones } \\
\end{array}$ \\
\hline GROUNDWATER FLOW & \multicolumn{3}{|c|}{ essentialy local } & mainly basin scale \\
\hline \multicolumn{5}{|l|}{ RESOURCE PERSPECTIVE } \\
\hline depth top of aquifer ( $\mathbf{m}$ bgl) & $0-5$ & $0-30$ & $<50$ & $100-500$ \\
\hline aquifer thickness (m) & $<20$ & $20-50$ & $20-40$ & $50-200$ \\
\hline aquifer productivity (1/s) & $1-2$ & $5-50$ & $0.2-1$ & $10-50$ \\
\hline dynamic water-level (m bgl) & $<5$ & $5-20$ & $10-25$ & $50-200$ \\
\hline \multicolumn{5}{|l|}{ USE PERSPECTIVE } \\
\hline salinity issues & none & possible & none & possible \\
\hline pollution hazard & high & medium & high & low \\
\hline natural water quality & good & some concern & good & some concern \\
\hline use potential & rural & rural $\%$ /urban ${ }^{*}$ & rural/urban * & rural \%/urban \\
\hline
\end{tabular}

Figure 1

Hydrogeological sketch map of Sub-Saharan Africa with indicative characteristics of the major aquifer categories (in part after BGS, 2011) basis for planning investment in detailed local evaluation and development, a DfID Project (BGS, 2011) has systematically interpreted and extrapolated available hydrogeological information at regional reconnaissance scale in terms of:

- Short-term water-well yield potential as an indicator of possible uses

- Drainable natural aquifer storage and as an indicator of drought resilience

- Potential rates of diffuse rainfall recharge as an indicator of resource sustainability.

It is recognised (especially in the drier parts of the region) that significant groundwater recharge only occurs as a consequence of major rainfall episodes - and that the periods for which water-well abstraction would need to be sustained from drainable aquifer storage alone could be on a 'decadal time-scale'.

A large part of the Sub-Saharan land area is underlain by 3 broad aquifer classes, whose general distribution and characteristics are given in Fig. 1:

- Weathered crystalline basement - an extensive but patchy shallow aquifer of low yield and storage potential, which only consistently provides water wells with drought yields of $1.0+\ell / \mathrm{s}$ (sufficient for motorised pumping) in limited areas of basement depression with overlying colluvial deposits.

- Some consolidated sedimentary rocks - limestones and sandstones forming deeper aquifers of variable recharge but with prospect of larger water-well yields albeit at higher construction costs. In the most arid parts of the region these formations may contain essentially non-renewable groundwater storage reserves, whose development should be subjected to special criteria (Foster and Loucks, 2006).

- Major alluvial formations and minor alluvial deposits forming shallow unconsolidated aquifers, usually providing 
moderate water-well yields and having relatively favourable recharge rates, but generally of much more limited extension (except in parts of western Africa).

In Sub-Saharan Africa current levels of groundwater development are generally low and the region is mainly experiencing 'economic water scarcity' due to lack of infrastructure investment (rather than absolute 'water resource scarcity'). Thus the priority must be for more effective planning and sustainable implementation of groundwater development (often in minor aquifers) to help meet critical social welfare targets and livelihood opportunities - managed groundwater development being a vital 'cog-in-the-wheel' of the overall future development process.

\section{Expanding irrigated agricultural production}

\section{Current position on groundwater irrigation}

Agricultural growth is the key to reducing rural poverty in Sub-Saharan Africa and political leaders have flagged it as critical for future investment. The scope for a major increase in water-well use to accelerate expansion of irrigated agriculture is an important topic of current debate in developmental circles, which goes well beyond the (now long-standing) beneficial practice of using excess flows from village hand-pump water wells for manual 'garden-scale' vegetable irrigation to contemplate (Tuinhof et al., 2011):

- Extensive groundwater use for small-scale irrigation on village communal land and by smallholders (using low-cost water wells) for horticulture and even drought-proofing staple-crop production

- Much more localised and intensive use of groundwater as a basis for commercial irrigation investments to produce 'cash crops' for national and international markets.

At present only a small proportion of Sub-Saharan agricultural land is equipped for irrigated cropping, and agricultural groundwater use in particular is extremely limited - a recent UN-FAO assessment (Siebert et al., 2010), based on satellite imagery and survey returns, estimated $0.4 \mathrm{M}$ ha in total (only $6 \%$ of all irrigated land and less than $1 \%$ of all arable land). Nevertheless, a recent IFPRI study of farmer response to climatic stress suggests that where governments have an explicit policy of promoting small-scale irrigation (e.g. Kenya, Nigeria) there has been significant uptake. Relatively successful examples, although not without some local problems, include:

- 'Fadama development' using shallow boreholes with motorised pumping to replace unstable hand-dug wells on the flood plains of northern Nigeria (Tuinhof et al., 2011)

- A substantial increase in supplementary manual irrigation from hand-dug wells in the weathered basement aquifer of the White Volta Basin in northern Ghana for horticulture (Barry et al., 2010)

- Commercial high-value irrigated crop production using limestone aquifers, for example, in parts of the Mpongwe Aquifer in Zambia.

Elsewhere, groundwater irrigation has often been beset by operational and/or economic problems, such as import restrictions on water-well equipment, absence of a related service sector, diesel energy costs and supply chains, post-harvest crop handling and transport, and inadequate access to markets. In addition, data scarcity, lack of understanding and poor appreciation of the groundwater resource has inhibited investment.

\section{Hydrogeological and social constraints on development}

The Africa Infrastructure Country Diagnostic (AICD) (Foster and Briceno-Garmendia, 2010) suggests that investment in small-scale irrigation might be viable on an additional 5.4 M ha of agricultural land to mitigate drought impacts and stem the rising cost of food imports, but this would be highly dependent upon keeping capital cost down to US\$ 2 000/ha and focusing on high-value crops (raising in excess of US\$ 2 000/ha). Moreover, the current widespread failure of irrigated production to buffer the volatility of rain-fed agriculture and secure national markets implies a pressing need to structure smallscale irrigation initiatives to address local market demands and to enhance crop water-use productivity (Riddle et al., 2006). The possibility of staple-crop irrigation is currently considered to be at best marginally economic, although some believe that supplementary small-scale low-cost groundwater irrigation of such crops to reduce drought impacts could become much more significant under some climate-change scenarios.

The question arises as to what proportion of any major expansion of irrigated agriculture might be based on groundwater use (based mainly on low-cost motorised water wells rather manual pumping techniques, such as hand and treadle pumps) - although it should also be recognised that various factors (such as a general lack of community tradition, the high capital-cost of water-well drilling, low levels of rural electrification and inadequate farmer access to financial credits) currently combine to constrain greatly significant demand for groundwater irrigation (Giordano, 2009).

On the specifics of groundwater development and resource sustainability the critical questions are:

- Can the cost of equipped water wells appropriate to local hydrogeological conditions be generally brought down to the level that makes the required investments economically feasible?

- How widely will hydrogeological conditions offer good prospects of obtaining sufficient yields for motorised pumping (say $1.0+\ell / \mathrm{s}$ ) from low-cost water wells (say at less than $30 \mathrm{~m}$ depth)?

- What level of 'irrigation intensity' will be sustainable in the longer-term, in areas where the water-well yield prospects are favourable, given probable natural rates of groundwater recharge and the possibility of their managed enhancement at low cost?

The answer to these questions is not straightforward, and there will be rather wide national and local variation. But the 'resource constraints' discussed above would appear to limit significantly the land area offering reasonable prospect of meeting these criteria (Tuinhof et al., 2011) - given that extensive areas are underlain by the weathered crystalline basement aquifer which only exceptionally appears to possess the yield potential encountered more widely in groundwater irrigation areas of Peninsular India (Chilton and Foster, 1995; Foster, 2012) and that most other aquifers in the more arid areas have 'depth-to-water' in excess of $30 \mathrm{~m}$ implying relatively expensive water wells and high pumping costs. Thus (despite considerable interest among foreign investors) the implication is that capital investment in groundwater-irrigated agriculture in Sub-Saharan Africa widely remains subject to significant obstacles and fairly high risks. Important exceptions, however, are the floodplains of major rivers (especially in western Africa) and margins of some lakes, where alluvial formations 
have shallow water-table, useful annual replenishment and are amenable to low-cost borehole construction (as an alternative to hand-dug wells).

\section{Stimulating and managing sustainable irrigation use}

Another question which arises is what can be done to reduce investment risks in irrigated agriculture - as far as the groundwater supply and resource sustainability dimensions are concerned. Beyond finding ways to bring down water-well construction costs, various actions could be taken by the national and regional groundwater agencies to help stimulate, channel and focus the increasing interest in expanding irrigated agriculture, whilst concomitantly avoiding excessive and unsustainable groundwater abstraction impacting negatively on the potable water-supply function of the resource:

- Further mapping and dissemination of groundwater availability data at national and provincial level, which should be collated with agricultural soils data as baseline planning information to judge the feasibility of major investment and viability of loan-finance to stimulate small-scale irrigation

- Incorporating groundwater recharge enhancement into rural development projects where feasible to provide additional 'buffering' storage during drought to support smallscale irrigation

- More detailed processing and presentation of hydrogeological information on water-well yield prospects and groundwater resource potential, in areas within $50 \mathrm{~km}$ of major market centres and international airports, to reduce the investment risk of private irrigation water-well drilling

- Undertaking multidisciplinary (hydrogeological and agroeconomic) post-case analysis of successful (and unsuccessful) examples of groundwater irrigation at all scales, so as to build a more robust platform for project design and investment

- Promoting highly focused and closely monitored pilot projects in a variety of hydrogeological and socioeconomic settings to guide cost-effective and sustainable expansion of groundwater-based irrigation - for this, promotion of alternative drilling techniques and pump energy sources, and using investment to set up private-sector services to sustain initiatives, are of special interest.

Experience from Asia and Latin America (Garduno and Foster, 2010) suggests that:

- Where major aquifers in relatively arid regions are subject to exploitation for commercial crop irrigation it is imperative (as early as possible) to impose effective groundwaterresource management in cooperation with users, so as to avoid counter-productive competition, negative side-effects and (in some cases) insidious salinisation - and this should normally include a system of groundwater-use rights, permits or allocations (subject to periodic review and constraint on transfer), the ability to impose a consistent ban on new water-well drilling, charging a 'resource use fee' to cover monitoring costs and effective sanctions for non-compliance.

- In the case of local groundwater bodies used for the irrigation of subsistence crops by large numbers of individually small users, it may be possible for government agencies to promote and nurture community self-regulation of groundwater resources through education and empowerment of the community with financial and technical support for introducing 'real irrigation water-savings' and higher-value, lower water-use, crops.

\section{Improving urban water-supply security}

\section{Current position on urban groundwater use}

The rapid growth of urban population (in the range of $2 \%$ to $7 \%$ per annum) and of water demand (up to $10 \%$ per annum), both in megacities and medium-sized towns, is a current reality in Sub-Saharan Africa - and is likely to be further accentuated in some climate-change scenarios as a result of migration from rural areas and increased ambient temperatures. The best information on urban water-supply status is contained in various AICD Reports of 2007 on household access to (and cost of) infrastructure services (Foster and Briceno-Garmendia, 2010), which were based on 63 large-scale surveys in 30 African countries that were scaled-up to provide the following average regional estimates:

- Almost $80 \%$ of the urban population have access to an 'improved water source' (although the proportion actually may have declined in recent years due to very rapid population growth), but there is substantial variation between more- and less-urbanised countries.

- Only 38\% of the urban population are served by mains water supply piped to dwellings, although a further $29 \%$ do have access to a municipal communal standpipe at a distance of less than $500 \mathrm{~m}$ away from the home.

- Collection from stand-alone water wells (constructed by municipality, community or privately) provides water for a further $24 \%$ of the urban population and is the fastest growing source generally, serving an additional $2.5 \%$ to $6.5 \%$ of the urban population per annum in various countries (such as Nigeria, Uganda, Mozambique and Malawi).

- The balance is made up by purchase from water vendors and collection from unsafe surface water sources.

The use of groundwater resources is not confined to standalone water wells, since in some cases they also provide part of the municipal piped water supply and in many others water supply is reticulated to communal standpipes (Tuinhof et al., 2011). Easy access to groundwater is often critical for poor urban dwellers (Gronwall et al., 2010). Moreover, the figures reflect numbers of users, not volume of abstraction, and do not consider other urban direct self-supply (commercial and industrial) use, most of which is groundwater. No inventory of urban groundwater dependence exists but substantial public and/or private use is understood to occur in Lusaka, Ndola, Maputo, Kampala, Dakar, Abidjan, Nairobi, Dar-es-Salaam and Addis Ababa (and probably elsewhere), with provisional estimates for the latter 3 cities all exceeding $100 \mathrm{M} \ell / \mathrm{d}$ and including significant private use.

The AICD water-sector reports also reveal the following average position as regards the provision of sanitation for the urban population:

- $65 \%$ are dependent upon in-situ sanitation (mainly the basic pit latrine) and around $10 \%$ have no sanitation system whatsoever.

- $25 \%$ have a 'flush toilet'; some of these are in fact connected to septic tanks, and it is only in the larger cities of middleincome countries (plus a few exceptions like Senegal) that waterborne sewerage has significant coverage.

In most urban areas only a minor proportion of pit latrines are emptied as recommended in operational guidelines, implying a large subsurface contaminant load as clearly reflected in groundwater pollution case histories from a UNEP-UNESCO funded 
programme (Xu and Usher, 2006). The level and complexity of pollution pressure will be sometimes augmented by industrial effluent disposal, hydrocarbon spillage and leachates from solidwaste tipping. Whilst the risk of faecal groundwater pollution should be limited to the most vulnerable hydrogeological conditions, it also remains a widespread problem because of inappropriate in-situ sanitation unit design/operation and inadequate water-well sanitary completion.

Groundwater development (in one form or another) generally represents the lowest-cost option and thus (even accepting quality hazards) must always be considered a potentially important component of future urban water-supply development (Tuinhof et al., 2011). The most probable future trend will be expansion of low-cost facilities such as water wells (with reticulation to standpipes where feasible) and improved pit latrines for sanitation. Thus various tools should be developed to facilitate more informed and ordered development of groundwater resources in urban areas including:

- Maps of water-well yield potential, depth to main aquifer horizons, static groundwater levels (as partial indicator of pumping lift), groundwater pollution vulnerability and natural quality hazards

- Order-of-magnitude assessments of groundwater-resource status, levels of sustainability and seriousness of risks associated with persistent excessive abstraction

- Monitoring abstraction and water tables - and making this information easily accessible

- Disseminating protocols requiring rain-water harvesting from rooftops and paved areas with enhancement of aquifer recharge through soakaways and avoiding unnecessary soil compaction in the urban environment

- Guidelines on groundwater use precautions in relation to potential and actual quality hazards.

There is also a pressing need to develop, disseminate and apply protocols for improved water-well design and construction, and the operation and maintenance of more 'groundwater-friendly' in-situ sanitation units (dry latrines and septic tanks) (Xu and Braune, 2010).

\section{Coping with escalating small-town water-supply demand}

Innumerable small- to medium-sized towns depend on groundwater (water wells, springs) for their municipal water supply but as a result of poor design, siting and/or maintenance, many sources perform considerably below potential in terms of yield provided, energy consumed and/or pollution experienced. It is now widely recognised that urban population growth (together with the fact that shallow aquifers are more vulnerable to contamination from high-density and/or inadequately-designed in-situ sanitation) is leading to a need to develop new sources on the outskirts of towns with sufficiently large individual yields to support motorised pumps and supply reticulated water-distribution systems (Tuinhof et al., 2011).

The larger investments involved make it vital to put more effort into better use of hydrogeological information for efficient water-well siting and design, and for defining local aquifer and wellhead protection zones (Foster et al., 2002). Much improved groundwater-source and aquifer monitoring will also be needed to provide a logical basis for designing the periodic expansion of municipal water services in years to come. Investment programmes should be used systematically to build capacity in the private sector to construct high-quality water wells and to undertake related hydrogeological investigations.

\section{Major groundwater development for municipal water- supply}

Some cities are underlain by important aquifers which provide the principal source of both utility and private water supply (e.g. Lusaka, Abidijan), with groundwater being critical to the continuity of the existing water-supply system. In a few cases this groundwater use has evolved as part of planned urban water-supply development, but more often it has been in shortterm response to new demand centres and increasing water shortage. The main issues in respect of groundwater use for small-town water supply are replicated and multiplied in larger urban centres (Tuinhof et al., 2011). In particular, wastewater infiltration (by one route or another) is a growing threat to groundwater quality and its control a high-priority measure for quality protection, whilst excessive local abstraction may also be a concern especially in some coastal areas. In the future, more formalised conjunctive use of groundwater and surface water will be needed to achieve greater urban water-supply security in drought. Successful examples of such practice to improve megacity water security and to stabilise the strategic reserves of urban aquifers in developing cities include Lima in Peru and Bangkok in Thailand (Foster et al., 2010).

Where the hydrogeological setting is favourable and megacities have highly productive aquifers in their proximity (e.g. Addis Ababa, Dar-es-Salaam) there may be potential for major new groundwater resources to be developed through well-field construction - this has the added benefit of providing access to large natural storage reserves which can act as a 'buffer' for climate-change adaptation (Tuinhof et al., 2011). The development of such groundwater resources will require substantial investment, with a systematic approach including step-wise investigation, phased monitored development and parallel action to preserve recharge areas and protect dependent ecosystems.

\section{Potential growth of in-situ residential self-supply}

Various megacities and many large towns are underlain by relatively low-yielding aquifers, which are being developed by a range of users in response to inadequate service of the utility mains water supply (e.g. Nairobi, Harare). Whilst waterwell construction costs have (incidentally) tended to moderate pressure on available groundwater resources, with economic development the demand for direct self-supply from groundwater by residential, commercial and industrial users is likely to grow substantially. At present water-well construction costs are significantly higher than in Latin America and much higher than in South Asia, where major private direct self-supply from groundwater has:

- Usually been initiated at individual urbanisation level as a 'coping strategy' during times of inadequate municipal utility provision

- Continued for 'cost economy' reasons (given the 'sunk capital') to avoid paying the higher tariffs of municipal utility services when these are augmented with new (more costly) 'imported-water' sources.

This expansion of groundwater use has been almost regardless of quality concerns (Foster et al., 2010). There is thus a need to identify more pragmatic ways of 'living with' urban quality deterioration through: 
- Providing incentives for logical types of private urban groundwater use - such as domestic toilet flushing, laundry, amenity irrigation, non-sensitive industries, cooling water, etc.

- Being aware of potential long-term operational and financial problems created by large-scale residential in situ self-supply, and the potential public health hazard in highly vulnerable aquifers

- Considering measures to reduce subsurface contaminant load - especially regular emptying of existing in situ sanitation facilities, introducing dry or eco-sanitation units, prioritising mains sewerage in areas of high aquifer pollution vulnerability and/or industrial effluent generation.

Moreover, in the longer run it will always be beneficial to register private groundwater sources, to improve urban waterwell sanitary completion and wellhead protection (Foster et al., 2002), and to enhance aquifer recharge by rain-water harvesting from rooftops and paved areas.

\section{Required institutional response}

\section{Integrating groundwater at national policy level}

The emerging developmental agenda in Sub-Saharan Africa will require much greater emphasis on strategic assessment and investment planning for groundwater resources, as a platform for managed groundwater development (Tuinhof et al., 2011). The 'new agenda' will require significant strengthening, evolution and, in some cases, reform of the institutional framework for groundwater governance (Foster et al., 2009). It will also require achieving a sensible (and in some cases delicate) balance between:

- Promoting (or providing an enabling framework for) much needed groundwater development

- Regulating groundwater abstraction and potentially polluting activities to avoid excessive resource exploitation and subsurface contaminant pressure in critical areas

- Integrating groundwater assessment, development and recharge-enhancement programmes with land-use management.

In many countries, the institutional landscape into which groundwater-resource development, management and protection has to be accommodated is also undergoing substantial change - as the result of a general trend for decentralisation with the formation of river-basin boards and/or agencies primarily to address 'upstream-downstream issues' of major river systems. This represents both an important opportunity and a significant complication for groundwater governance. Over 60 such organisations have been formed, or are being formed, in the region - although only a minority of these have, as yet, significant operational capacity and/or actively include groundwater management and protection.

The integration of groundwater into national policy, such that this resource can make an appropriate and effective contribution to economic development plans (relating to issues like food security, urban services and rural livelihoods) requires developing an adequate cross-sector dialogue within government. This, and accommodating the particular needs of groundwater within the river-basin board/agency structure, makes it absolutely essential for political awareness of groundwater at the highest level, and the recent initiatives by both SADC (Tuinhof et al., 2011) and AMCOW in this regard are most timely.

\section{Strengthening the essential roles of government}

Broad international consensus now exists that the primary government function must be to act on behalf of civil society as 'custodian', 'guardian' or 'trustee' of renewable natural resources like groundwater, and that the related legislation should be flexible, enabling and enforceable. The essential roles of government are thus best defined legally in terms of certain fundamental concepts, responsibilities and powers (with the detail being handled through associated regulations and implementation plans):

- Catchment/aquifer-level resource planning and allocation - establishing sensible boundaries for resource management, translating national plans to the appropriate territorial level and providing a unified vision of groundwater and surface water resources

- Land surface zoning for groundwater conservation and/ or protection - making provision for the declaration of 'special control areas', critical in resource terms or especially vulnerable in pollution terms, where exceptional measures can be implemented

- Groundwater monitoring and information provision ensuring appropriate monitoring, together with periodic evaluation of resource status based on open data exchange and information provision

- Facilitating stakeholder participation and engagement - the active involvement of groundwater users and potential polluters, and other interest groups being necessary to promote and enforce balanced development and protection on-the-ground

- Administration of groundwater resource use - according to the overarching allocation plan and including waterwell construction permits, registers, abstraction rights/ permits, and resource charging (as appropriate), together with effective sanctions for non-compliance

- Licensing of ground discharge of wastewater and landfill waste disposal - subject to conditions that prevent or limit groundwater pollution, with effective sanctions for non-compliance.

A GW-MATE review of national legal provisions for groundwater (in the SADC member states) indicated that the majority already had most of the above concepts, responsibilities and powers embodied in their legislative framework. However, the institutional capacity required to implement such provisions at local level is rarely achieved because of:

- Serious lack of experienced or well-trained staff in government agencies (and perhaps more generally)

- Inadequate budgets for fundamental activities like waterwell registration and groundwater monitoring

- Insufficient attention to priority-setting so as to concentrate on the most critical issues and areas, and to create an 'enabling environment' for management with relevant stakeholders.

To achieve managed groundwater development it will be necessary for governments to make efforts in:

- Professional capacity building - through the provision of training (and training-the-trainers) to develop additional capacity and deploying existing personnel more effectively

- Stimulating successful private-sector participation - so as to provide quality contracting services (in water-well siting, construction and maintenance) and/or competent professional consultancy services (in surveying, evaluation and monitoring of groundwater) consistently 


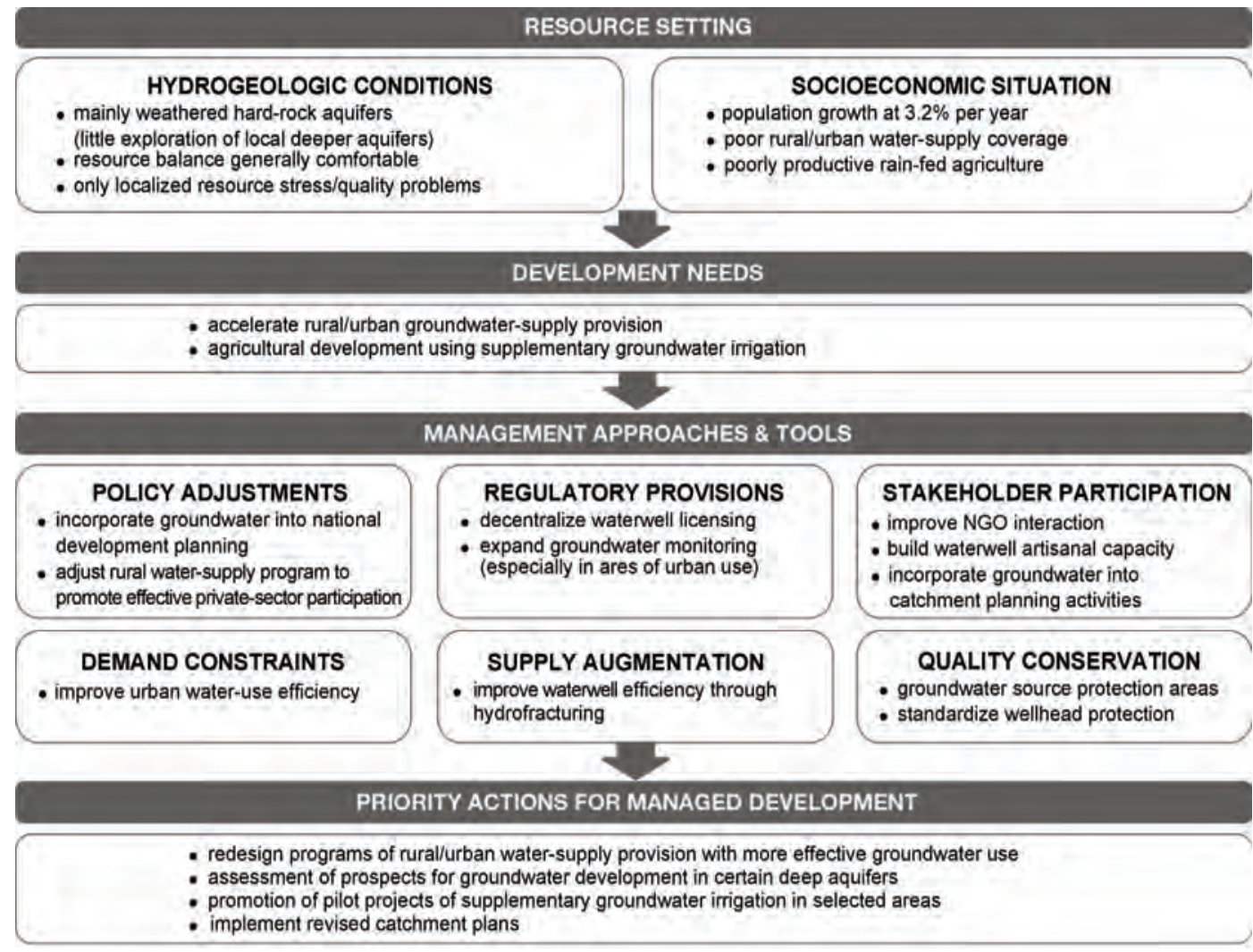

- Ensuring that the relevant government agency has the professional capacity and institutional strength to guide and assess the quality of the work commissioned to the private sector.

These efforts will be integral to improving resource management and protection (Tuinhof et al., 2011).

Groundwater is essentially a 'local resource' (when it comes to use and protection), and to be effective its day-to-day management has to take place close to its users and potential polluters, but within a national framework. There is thus need for locally-based offices of the responsible government agency or ministry - and the existence of local subcatchment or district water-resource-management offices makes this possible, whilst avoiding potential conflicts of interest that can arise if this function is entirely delegated to provincial government. However, when it comes to groundwater, decentralisation also poses a major concern as regards 'critical professional mass' and 'experienced leadership' - and pragmatic compromises will often be necessary to get the organisational balance right (Tuinhof et al., 2011). Local action to manage groundwater will also always require some direction and facilitation on a 'top-down basis', so as to provide an effective technical and economic basis for management, empowerment from the 'higher level' to take the necessary action and an 'overview capacity' to review progress towards agreed objectives and targets - and a strong national focal-point is essential in this regard. There is also evidence from the SADC region that decentralisation has resulted in lack of long-term commitment to field monitoring and data archiving, which is especially critical to the understanding and management of groundwater (Robins et al., 2006). It is thus necessary to entrust the collection and collation of hydrogeological data (together with its transparent dissemination to all interest groups) to a 'dedicated national centre', but linked to the decentralised system of groundwater resource administration.

\section{Effective co-ordination on urban groundwater issues}

Urban groundwater tends to affect everyone - but all too often is the clear responsibility of no one! It is evident that in virtually all cases more effort needs to go into the development of appropriate policies for urban groundwater and on evaluating, managing and protecting the groundwater resource - and for this it will be essential to understand the dynamics of present and future use (Foster et al., 2010).

Given the critical role that groundwater can play in the water-supply security of many African cities (even where most of its development has been under private rather than municipal initiative), there is an urgent need for strategic (hydrogeological and socio-economic) assessment of its current utilisation and implementing management actions to ensure future availability and greater integration with surface water-supply. In all such cases an appraisal of groundwater recharge, storage potential and pollution risk will be needed. The special conditions in fast-growing urban centres mean that this will require an integrated effort involving a consortium of empowered representatives from the water resource regulator (where such exists), the water-supply service utility, the public-health authority and the municipal land-use planning agency. This consortium would benefit from a mechanism for community consultation and the work of a technical support group to investigate and report back on specific issues.

\section{A pragmatic framework for prioritising actions}

Conscious of the need to focus and prioritise government actions on 'managed groundwater development' through structured interaction with stakeholders, GW-MATE developed a pragmatic framework for groundwater policy analysis and institutional responsibility (Fig. 2). The framework also 
provides a practical approach for deciding on cost-effective and sustainable investment in groundwater development, based on a systematic analysis and realistic targets (Tuinhof et al., 2011). Once elaborated at national level the framework can then also serve as a reference for application at the more local level. A most important aspect of this framework is its use to formulate a limited number of priority actions endorsed by the main stakeholders.

Sub-Saharan Africa does not generally experience the 'classical problems' associated with excessive groundwater development, other than on a local basis, and the need for 'conventional groundwater resource management' is limited to a few 'hotspots'. But most countries need to address specific challenges by:

- Improving the efficiency of groundwater use for rural water supply over extensive areas, which requires cost-effective water-well drilling and investing in data collection and information processing

- Realistic planning, sustainable utilisation and effective protection of groundwater resources (often in minor aquifers) to promote economical groundwater irrigation where feasible, and to confront the urban water-supply challenge, and thereby meet specific social-welfare targets

- Mobilising communities to value, maintain and protect their groundwater sources, supporting them with better understanding, budgetary provision and appropriate local guidelines and regulations.

\section{Acknowledgements}

The authors express their thanks to the World Bank GW-MATE Programme Managers (Catherine Tovey and Amal Talbi), the World Bank Water Anchor (Julia Bucknall and Marcus Wijnen) and the Global Water Partnership (Ania Grobicki and Aurelie Vitry) for their encouragement and facilitation of this strategic overview - although the opinions expressed are those of the authors alone and not necessarily of the World Bank or the Global Water Partnership. The related GW-MATE experience arose mainly from the World Bank's Africa Department supported projects, and the contribution of Ashok Subramanian, Marcus Wishart and Rafik Hirji is especially acknowledged, together with that of numerous staff members of the Governments of Ethiopia, Tanzania and Uganda, and of SADC. The helpful advice of Jacob Burke (UN-FAO), Alan Macdonald (BGS), Willi Struckmeier (BGR) and John Chilton (IAH) are also gratefully acknowledged.

\section{References}

BGS (2011) Groundwater Resilience to Climate Change in Africa. British Geological Survey Groundwater Science Programme Open Report OR/11/031. British Geological Survey, Nottingham, UK. URL: www.bgs.ac.uk (Accessed September 2011).

BARRY B, KORTATSI B, FORKOUR G, KRISHNA-GUMMA M, NAMARA R, REBELO L-M, VAN DEN BERG J and LAUBE W (2010) Shallow Groundwater in the Atankwidi Catchment of White Volta Basin - Current Status and Future Sustainability. IWMI Research Report 139. IWMI, Colombo, Sri Lanka.
CHILTON PJ and FOSTER SSD (1995) Hydrogeological characterization and water-supply potential of basement aquifers in tropical Africa. Hydrogeol. J. 3 36-49.

FOSTER S (1984) African groundwater development - the challenges for hydrological science. IAHS Publ. 144 3-12.

FOSTER S, HIRATA R, GOMES D, D'ELIA M and PARIS M (2002) Groundwater Quality Protection - A Guide for Water Utilities, Municipal Authorities and Environment Agencies. World Bank, Washington DC, USA.

FOSTER S, GARDUNO H, TUINHOF A and TOVEY C (2009) Groundwater Governance - Conceptual Framework for Assessment of Provisions and Needs. GW-MATE Strategic Overview Series 1. World Bank, Washington DC, USA. URL: www.worldbank.org/gwmate (Accessed July 2011).

FOSTER S, HIRATA R, MISRA S and GARDUNO H (2010) Urban Groundwater Use Policy - Balancing the Benefits and Risks in Developing Nations. GW-MATE Strategic Overview Series 3. World Bank, Washington DC, USA. URL: www.worldbank.org/ gwmate (Accessed July 2011).

FOSTER S (2012) Hard-rock aquifers in tropical regions - using science to inform development and management policy. Hydrogeol. J. 20 659-672.

FOSTER S and LOUCKS DP (eds.) (2006) Non-Renewable Groundwater Resources - A Guidebook on Socially-Sustainable Management for Water-Policy Makers. UNESCO IHP-VI Series on Groundwater 10. UNESCO IHP, Paris.

FOSTER V and BRICENO-GARMENDIA C (eds.) (2010) Africa's Infrastructure - A Time for Transformation. World Bank/Agence Francaise de Developpement - AICD Development Forum Series. Washington DC, USA.

GARDUNO H and FOSTER S (2010) Sustainable Groundwater Irrigation - Approaches to Reconciling Demand with Resources. GW-MATE Strategic Overview Series 4. World Bank, Washington DC, USA. URL: www.worldbank.org/gwmate (Accessed July 2011).

GRONWALL JT, MULENGA M and MCGRANANHAN G (2010)

Groundwater Self-Supply and Poor Dwellers - A Review with Case Studies of Bangalore and Lusaka. IIED - Human Settlements Programme Publication. IIED, London, UK.

GIORDANO M (2009) Agricultural groundwater use and rural livelihoods in Sub-Saharan Africa - a first-cut assessment. Hydrogeol. J. 14 310-318.

RIDDLE PJ, WESTLAKE M and BURKE J (2006) Demand for Products of Irrigated Agriculture in Sub-Saharan Africa. FAO Water Reports 31. UN-FAO, Rome, Italy.

ROBINS NS, DAVIES J, FARR JL and CALOW RC (2006) The changing role of hydrogeology in semi-arid southern and eastern Africa. Hydrogeol. J. 14 1483-1492.

SIEBERT S, BURKE J, FAURES J M, FRENKEN K, HOOGEVEEN J, DOELL P and PORTMAN F T (2010) Groundwater use for irrigation - a global inventory. Hydrol. Earth Syst. Sci. 14 1863-1880.

TUINHOF A, FOSTER S, STEENBERGEN F VAN, TALBI A and WISHART M (2011) Appropriate Groundwater Management for Sub-Saharan Africa - In Face of Demographic Pressure and Climatic Variability. GW-MATE Strategic Overview Series 5. World Bank, Washington DC-USA. URL: www.worldbank.org/ gwmate (Accessed July 2011).

WHYMAP (2008) Groundwater Resources Map of Africa. BGR Publication, Hannover, Germany. URL: www.whymap.org (Accessed June 2011).

XU Y and USHER B (eds.) (2006) Groundwater Pollution in Africa. Balkema Proceedings and Monographs in Engineering, Water and Earth Sciences. Taylor \& Francis/Balkema, London, UK.

XU Y and BRAUNE E (2010) Sustainable Groundwater Resources in Africa - Water-Supply and Sanitation Perspective. CRC Press/ Balkema, Leiden, The Netherlands. 